\title{
Os escritores românticos brasileiros e a tendência nacional-descritiva na literatura do século XIX
}

Eduardo Luis Araújo de Oliveira Batista ${ }^{a}$

\begin{abstract}
Resumo
A literatura romântica brasileira surgiu num momento de afirmação nacional e sob o influxo das ideias do francês Ferdinand Denis, autor da primeira história literária brasileira, publicada em 1826, na qual propôs à recém-fundada nação uma poética voltada para a representação da natureza tropical como índice de originalidade e nacionalidade. Considerando o pioneirismo de Denis em nosso movimento romântico, propomos, neste artigo, estudar as referências diretas e indiretas à proposta do francês nas obras e textos de importantes nomes da literatura brasileira ao longo do século XIX. Buscamos, para além das reverberações da proposta de Denis, apontar como nossos escritores adaptaram os ideais do francês para o contexto histórico-social brasileiro, assim como mostrar a reação de alguns autores que se colocaram contra essa vertente nacional-descritiva que norteou boa parte da produção literária brasileira romântica, inclusive na crítica e historiografia literária.
\end{abstract}

Palavras-chave: Ferdinand Denis; História da Literatura Brasileira; Romantismo.

Recebido em 30 de março de 2016 Aceito em 07 de julho de 2016

aPós-doutorando em Literatura, Universidade Federal do Espírito Santo (UFES). E-mail: eduardolaob@ yahoo.com.br 
A presença pioneira e marcante de Ferdinand Denis e sua obra no desenvolvimento do Romantismo literário brasileiro, já apontada por Antonio Candido em sua Formação da literatura brasileira, tem obtido constante atenção dos estudiosos da história da literatura. A proposta de Denis para a literatura brasileira, iniciada em seu livro Scènes de la nature sous les tropiques, et leur influence sur la poésie (1824) e formalizada em seu Resumé de l'Histoire Literaire du Brésil (1826), baseada na valorização da representação da natureza tropical como índice de originalidade e nacionalidade, é interpretada como um elemento ativador de nosso movimento romântico. Candido acentuou o lugar que a atuação de Ferdinand Denis ocupou nesse momento de surgimento do Romantismo no Brasil: segundo ele, "os estudos críticos de Magalhães e Pereira da Silva estabeleceram o ponto de partida para a teoria do nacionalismo literário, aclimatando as ideias de Denis, que lhe serviam de bússola" (CANDIDO, 1976, p. 13).

Para Maria Helena Rouanet (1991), Denis se notabilizou por sua ação tutorial sobre os escritores brasileiros, sendo considerado o mentor original das ideias românticas desenvolvidas pelos românticos das primeiras gerações, fazendo sugestões para que adotassem a temática brasileira em suas obras, ajudando a criar uma tradição literária nacional afirmada pelo passado colonial, e propondo o indianismo como imagem da identidade nacional. Como afirma Regina Zilberman a respeito da história literária de Denis, que adquiriu o formato de um manifesto no qual o autor apresentou sua proposta de uma literatura voltada para a representação da cor local:

[...] o Résumé teve grande impacto sobre os intelectuais brasileiros da primeira geração romântica, que copiaram muitas de suas afirmações sobre a necessidade de a literatura exibir um caráter nacional e dar vazão à cor local. Embora Ferdinand Denis não tenha sido o único a tomar essa posição -que se encontra igualmente no «Bosquejo da história da poesia e língua portuguesa», de Almeida Garrett (Garrett, 1826), prólogo do Parnaso Lusitano, de 1826- suas ideias foram utilizadas para reiterar a importância do trabalho pioneiro concretizado, por exemplo, por Gonçalves de Magalhães (18111882) nos anos 30 do século XIX (ZILBERMAN, 2013, p. 137).

Lucia Ricotta (2011) alinha a proposta literária de Denis presente em Scènes de la Nature sous les Tropiques e o programa 
apresentado por Gonçalves de Magalhães em seu "Discurso sobre a história da literatura do Brasil" (1836), à obra do naturalista alemão Alexander Humboldt, Visões da natureza. Para Ricotta, essa confluência se dá no movimento de "deitar as raízes das cenas de origem nas cenas tropicais da natureza":

O 'Ensaio', de Magalhães, publicado em Paris na Niterói, Revista Brasiliense, Ciências, Letras e Artes, de 1836, guarda ressonância do tópos das cenas da natureza promovido no Brasil por Ferdinand Denis. Scènes de la Nature sous le Tropiques, tomado doravante desde a perspectiva de Visões da Natureza, de Alexander von Humboldt, que lhe serve de referência, dará um sentido inédito à pintura da natureza tropical pelos românticos (RICOTTA, 2011, p. 116).

Tendo o romantismo brasileiro encontrado "na natureza um sentido de origem e fundação" (RICOTTA, 2011, p. 114), a autora ressalta o caráter programático do tema local como poética nacional que perpassa esses textos:

Nacionalizar as letras pelo topos das cenas representa a intenção programática de regrar o regime metafórico da essência nacional e transformar o nacional em regra de escrita. É notável como os românticos usam discursos referendados pela tradição, procedimentos narrativodescritivos da paisagem para adaptação de tópicas antigas. A origem e a originalidade que pretendem são muitas vezes possíveis somente como articulações de discursos tradicionais. Daí o caráter programático desse topos (RICOTA, 2011, p. 118).

Ainda que o caráter fundador dos textos de Denis seja quase indiscutível, a absorção de suas ideias, porém, não deixou de ser filtrada segundo os interesses dos brasileiros. Neste artigo, propomos estudar as referências diretas e indiretas à proposta de Denis nas obras e textos de alguns escritores brasileiros do século XIX como o já citado Gonçalves de Magalhães, além de outros como Álvares de Azevedo, José de Alencar e Machado de Assis. Mais do que buscar os ecos da proposta de Denis na obra dos escritores citados, buscamos, além de apontar a adaptação dos ideais do francês para o contexto histórico-social brasileiro, mostrar também a reação de alguns autores que se colocaram contra a camisa de força dessa vertente nacional-descritiva que norteou boa parte da produção literária brasileira romântica. Usado como critério 
de originalidade e mesmo de qualidade literária, o nacionaldescritivismo também se apresentou na crítica e historiografia literária da época e gerou polêmicas, como veremos.

A proposta de uma literatura nacional brasileira, formalizada por Ferdinand Denis em sua história literária publicada em 1826, foi lançada pelos brasileiros somente dez anos depois, pelo grupo que se formou em torno da revista Niterói, editada em Paris. Formado por Gonçalves de Magalhães, Porto Alegre, Torres Homem e outros, o grupo fundou a revista em 1836, em cuja primeira edição Gonçalves de Magalhães publicou seu "Discurso sobre a história da literatura no Brasil", tido como o manifesto do Romantismo brasileiro. No mesmo ano, Gonçalves de Magalhães publicou também seus Suspiros poéticos e saudades, considerada por muitos como a primeira obra romântica brasileira.

Se analisarmos o programa da nova geração romântica, apresentado no "Discurso sobre a história da literatura no Brasil", de Gonçalves de Magalhães, este não apenas segue o exemplo de Ferdinand Denis na utilização da historiografia como manifesto literário, mas também adota as ideias de Denis sobre a criação de uma literatura nacional brasileira, apresentadas em seu Resumé. Essa assimilação, no entanto, não é explicitada por Magalhães em seu texto. Denis é apenas citado como autor de uma história literária considerada a mais extensa até então produzida sobre o país, notando-se também a separação entre a literatura portuguesa e brasileira presente na obra. No entanto, para Magalhães a obra está "longe de ser completa, servindo apenas para dar uma ideia aos estrangeiros" (MAGALHÃES, 1974, p. 14).

$\mathrm{Na}$ "Advertência" que Magalhães fez a uma publicação posterior do seu "Discurso", já na década de 1860, o autor cita a obra historiográfica O Brasil literário (1863), de Ferdinand Wolf, como "o mais seguro e completo guia nesta matéria tanto aos nacionais quanto aos estrangeiros" (MAGALHÃES, 1974, p.12). Além de não reconhecer explicitamente sua filiação às ideias de Denis, Magalhães coloca a obra do francês em segundo plano. Apesar das poucas referências a Denis, mesmo nesse momento de aparente balanço apresentado na "Advertência" (em que cita, como realizadores da sua patriótica proposta apresentada no "Discurso", os nomes de Porto Alegre, Gonçalves Dias, Macedo, 
Teixeira e Souza e Norberto da Silva) as ideias do francês, porém, apresentam-se caracterizadas no texto de Magalhães. Como Denis em sua história literária, Magalhães se preocupa mais em definir os aspectos ideais para o desenvolvimento de nossa literatura nacional, do que estabelecer um panorama histórico de sua produção. Como ele próprio afirma, "jamais uma Nação poderá prever o seu futuro, se não conhece o que ela é comparativamente com o que ela foi. Estudar o passado é ver melhor o presente, é saber como se deve marchar para um futuro brilhante" (Ibid., p. 19), repetindo o paradoxo de Denis de propor uma história que se projeta para o futuro, como se pode entrever no subtítulo da obra: Considerações gerais sobre o caráter que a poesia deve assumir no Novo Mundo (DENIS, 1978, p. 35). Mesmo nesse quesito, o de um programa, ele não se aprofunda muito, e recheia seu texto de retórica antilusitana, por meio da qual justifica as limitações de nossa literatura, num misto de afirmação política e projeto literário. A historiografia, assim, acaba ficando relegada a esparsas referências, sem que nenhum autor, obra ou movimento literário brasileiro seja citado em todo o texto. Como bem qualificou José Veríssimo na Introdução de sua História da literatura brasileira, "Magalhães apenas mostrou sua ignorância do assunto, que não estudou, limitando-se a uma amplificação retórica" (VERÍSSIMO, 1963, p. 18). Além da forma da historiografia (pelo menos em seu título), o "Discurso" de Magalhães apresenta as mesmas propostas e críticas para nossa literatura estabelecidas de forma inédita por Denis: a crítica ao uso de imagens mitológicas como tema literário, a proposta da descrição da natureza brasileira, e a elevação do indígena e de sua cultura ao status de uma origem cultural brasileira. Com relação ao uso da mitologia por nossos poetas, afirma, quase parafraseando Denis:

O que mais dá realce e nomeada a alguns dos nossos poetas não é certamente o uso dessas sediças fábulas, mas sim outras belezas naturais, não colhidas nos livros, e que só o céu da pátria lhes inspirará. Tão grande foi a influência que sobre o engenho brasileiro exerceu a grega mitologia, transportada pelos poetas portugueses, que muitas vezes poetas brasileiros se metamorfoseiam em pastores da Arcádia, e vão apascentar seus rebanhos imaginários nas margens do Tejo e cantar à sombra das faias (MAGALHÃES, 1974, p. 20). 
Ferdinand Denis havia afirmado, em 1826, "se essa parte da América adotou uma língua que a nossa velha Europa aperfeiçoara, deve rejeitar as ideias mitológicas devidas às fábulas da Grécia" (DENIS, 1978, p. 36). Magalhães concorda também com a ideia apresentada por Denis de que a natureza determina a criação poética, e que uma natureza nova deve gerar uma nova literatura, afirmando em seu Discurso: "o homem colocado diante de um vasto mar, ou no cume de uma alta montanha, ou no meio de uma virgem e emaranhada floresta, não poderá ter por longo tempo os mesmos pensamentos, as mesmas inspirações [...]" (MAGALHÃES, 1974, p. 20). A natureza brasileira, segundo Magalhães, deveria substituir as paisagens europeias como fonte de inspiração para nossa literatura, e os testemunhos dos viajantes estrangeiros são invocados como aval de sua pujança, lembrando ainda o mote de Denis de que, num país de poucas realizações culturais, a grandiosidade da natureza toma primeiro plano. É o que podemos ver na seguinte declaração de Magalhães em seu Discurso:

Vimos esse céu que cobre as ruínas do Capitólio e do Coliseu. Sim, é belo esse céu, mas o do Brasil não lhe cede em beleza! Falem por nós todos os viajores que, por estrangeiros, não os tacharão de suspeitos. Sem dúvida que eles fazem justiça e o coração do Brasileiro, não tendo por hora muito do que se ensoberbeça quanto às produções das humanas fadigas, que só com o tempo se acumulam, enche-se de prazer e palpita de satisfação, lendo as brilhantes páginas de Langsdorff, Neuwied, Spix et Martius, Saint-Hilaire, Debret e de tantos outros viajores que revelaram à Europa as belezas da nossa pátria (MAGALHÃES, 1974, p.23).

O indígena, por sua vez, é valorizado através de uma idealização que lembra as qualidades louvadas por Denis, como seu amor pela liberdade, ou sua coragem. Assim, para Magalhães, os índios são considerados como "sendo tão amigos da liberdade que, para evitar o cativeiro, caíam, de preferência, debaixo dos arcabuzes dos Portugueses que tentavam submetêlos ao seu jugo tirânico!" (Ibid., p. 25), enquanto Denis havia defendido em seu Resumé, "que terão, portanto, de inferior aos heróis dos tempos fabulosos da Grécia esses homens (os indígenas) de quem não se podia arrancar um só lamento [...]" (DENIS, 1978, p. 37). 
A filiação à cultura francesa é vista por Magalhães como sinal de desenvolvimento e como contraponto ao fim do poder colonial português: "com a expiração do domínio português muito se desenvolveram as ideias. Hoje o Brasil é filho da civilização francesa, e como Nação é filho dessa revolução famosa que abalou todos os tronos da Europa" (MAGALHÃES, 1974, p. 21). Dessa forma, Magalhães avaliza a posição de Denis de que a França deve oferecer o modelo cultural para jovem nação brasileira, tal como proposto em seu Resumé.

Talvez a maior diferença entre os dois programas, o de Denis e o de Magalhães, seja a ausência, no segundo, da questão da mestiçagem racial e cultural no Brasil. Denis defendeu em seu texto a particularidade brasileira da mestiçagem das três raças - portuguesa, indígena, e negra - vista de forma positiva como produtora de uma cultura única e original, que deveria ser representada na literatura. Ao propor a adoção, pela literatura, dos elementos da cultura nativa junto às das culturas transplantadas para a América, como fatores de sua especificidade cultural, Denis se tornou um dos primeiros intelectuais a reconhecer como positiva a união das três raças que formaram o Brasil, e considerar as possibilidades culturais da mestiçagem: "[...] o americano, no qual tantas raças se misturam [...] quer descenda do europeu, quer esteja ligado ao negro ou ao primitivo habitante da América, o brasileiro tem disposições naturais para receber impressões profundas" (DENIS, 1978, p. 38). E ressalta as qualidades de cada raça, "afigura-se que o gênio peculiar de tantas raças nele se patenteia: sucessivamente arrebatado, como o africano; cavalheiresco, como o guerreiro das margens do Tejo; sonhador, como o americano" (Idem). A literatura brasileira deveria, portanto, reunir em si as qualidades das três raças: o índio melancólico, que retém no fundo da alma a energia da independência e da liberdade que reina nas florestas; o negro, cujo calor da alma e credulidade faz o sobrenatural embelezar as narrativas, e que "dá vida, com as tradições poéticas da sua terra natal, à nova vida" (DENIS, 1978, p. 39); além do branco, que une as novas tradições às dos velhos tempos.

Mas, naquele momento de independência recémconquistada, louvar as qualidades da herança portuguesa se tornava um assunto delicado para os escritores nacionalistas brasileiros. Nesse sentido, num momento de afirmação de 
${ }^{1}$ Como afirma Bosi, em sua História concisa da literatura brasileira, o tema do negro teria sido tratado "precocemente" por Fagundes Varela em Mauro, o escravo, de 1864 Segundo Bosi, antes da campanha abolicionista só havia alusões esparsas ao escravo na poesia romântica. Quem teria precedido imediatamente Varela e Castro Alves foi Luis Gama (1830-1882), mulato, filho de uma africana livre e de um senhor branco, e que escreveu Primeiras trovas burlescas (1859), e Novas trovas burlescas (1861). (BOSI, 1975, p.131). Portanto, cerca de quase quarenta anos após a publicação do conto "Palmares", de Ferdinand Denis. liberdade política, é natural a oposição apresentada à herança colonial portuguesa. São, portanto, apenas os aspectos negativos da participação de Portugal na formação brasileira os lembrados no "Discurso". Magalhães considera a herança portuguesa como um impedimento ao desenvolvimento cultural do país, tanto por suas medidas de domínio colonial, como por sua influência cultural deletéria. A colonização portuguesa é, inclusive, responsabilizada pelo enxerto de temas estranhos e indesejados em nossa literatura:

Não se pode lisonjear muito o Brasil de dever a Portugal sua primeira educação, tão mesquinha foi ela que bem parece ter sido dada por mãos avaras e pobres; contudo boa ou má dele herdou, e o confessamos, a literatura e a poesia, que chegadas a este terreno americano não perderam o seu caráter europeu (MAGALHÃES, 1974, p. 19).

Se a herança portuguesa era rechaçada, especialmente por motivos políticos, por outro lado, a presença negra na cultura brasileira também era vista com desconfiança pela elite, isso devido à influência negativa que então se atribuía à miscigenação racial (ideia comum na época, contra a qual a voz de Denis soa dissonante), e ao desconforto moral aliado à dependência econômica que a presença da escravidão no país trazia. Não só o negro não é citado no "Discurso", como se mantém excluído como tema da literatura romântica brasileira por um longo período. Nos Suspiros poéticos..., o negro aparece apenas em um poema, "Invocação à saudade", um lamento contra a escravidão. ${ }^{1}$ Restou, portanto, o índio, já proposto por Denis, e que foi prontamente aceito, através de sua idealização, como símbolo de identidade nacional, gerando uma voga no século XIX que tomou conta não só da literatura, mas do próprio Império, que o adotou como imagem oficial, através, dentre outros exemplos, da concessão de títulos nobiliárquicos com nomes indígenas, e da adoção de sua imagem na pintura e decoração oficial como alegoria nacional.

A adoção por nossos românticos dos critérios literários apresentados por Denis, assimilados e apresentados no "Discurso", no entanto, deu-se paulatinamente. Na poesia, as ideias de Denis repercutiram principalmente na adoção do indianismo, do ufanismo nacionalista baseado na descrição das belezas naturais, e na recriação histórica. Na obra considerada inauguradora de nosso Romantismo, Suspiros poéticos e saudades, 
de Gonçalves de Magalhães, já podemos encontrar o embrião desses temas poéticos nacionalistas, ainda incipientes, mas que se desenvolverão com maior força posteriormente. A natureza brasileira, porém, nele ganha preeminência frente ao cenário europeu que cerca o poeta, inaugurando o topos do exílio tão largamente desenvolvido no Romantismo brasileiro. Os poemas de Suspiros poéticos lembram aos poetas brasileiros que é para sua pátria que devem voltar seus olhos, enquanto a tão desejada paisagem (natural e cultural) europeia apenas serve de pano de fundo para ressaltar a grandeza da natureza e do futuro do Brasil. Mas essa grandeza de nossa natureza e país aparece aqui apenas como uma lembrança, uma imagem difusa num sentimento de saudade, não atingindo o grau de descrição e particularidade em que se desenvolveria no nosso Romantismo.

O indianismo, que aparece como uma breve referência nessa primeira obra romântica, irá se desenvolver na poesia, segundo Candido, com a Nênia, de Firmino Rodrigues da Silva, de 1837, seguido por autores como Joaquim Noberto, Texeira e Souza, com seu poema indianista "Três dias de um noivado", de 1844, encontrando seu grande momento nos Primeiros cantos, de 1846, de Gonçalves Dias, autor que lhe daria sua forma mais definitiva em versos. O tema fez escola e se tornou quase obrigatório. O próprio Magalhães publicou Os Tamoios, em 1856, patrocinado por D. Pedro II, e até Machado de Assis compôs seus poemas indianistas, publicando suas Americanas (repletas de notas etnográficas, atestando a veracidade dos aspectos indígenas apresentados no poema, bem ao gosto de Denis), tardiamente, já em 1875. Ao lado dos demais elementos constituintes do movimento literário romântico brasileiro, como o subjetivismo, o individualismo, o lirismo, a religiosidade, interessa-nos levantar aqui, especialmente, aqueles definidos por Denis para a criação da literatura nacional brasileira: o indianismo, a descrição da natureza e dos costumes pitorescos e a recuperação da história colonial. Todos esses elementos propostos por Denis configuram uma tradição descritivista: uma literatura que busca descrever o país histórica, cultural e geograficamente, e que bebe direto da fonte da literatura de viagem. Se na poesia essa tendência se aprofundou através do indianismo e do épico histórico, foi na prosa que a descrição histórica, paisagística e de costumes avançou terreno. Como afirma Candido, "o nacionalismo, na literatura brasileira, consistiu basicamente em escrever sobre 
coisas locais: no romance, a consequência imediata e salutar foi a descrição de lugares, cenas, fatos e costumes do Brasil" (CANDIDO, 1976, p. 112). E essa tendência pode ser encontrada desde os nossos primeiros romances, como $O$ filho do pescador (1843), de Teixeira e Sousa, e A moreninha (1844), de Joaquim Manuel de Macedo, passando pela obra de José de Alencar e prosseguindo nas gerações românticas seguintes, até o regionalismo de Bernardo de Guimarães e Franklin Távora. Basicamente, esse descritivismo, na prosa, adquiriu, portanto, as formas do indianismo, do romance histórico, de costumes, e do regionalismo. Como lembra Candido, os escritores românticos realizaram na prática, o que Denis "doutrinou e exemplificou" (CANDIDO, 1976, p. 12).

Se Gonçalves Dias é o poeta por excelência do indianismo, na prosa o nome que mais se destacou foi o de José de Alencar. Alencar percorreu com desenvoltura os quatro grandes temas propostos por Denis e que citamos acima: o indianismo, o romance histórico, o de costumes e o regionalismo. $\mathrm{O}$ próprio Alencar estabelece a relação de suas obras com essas categorias literárias em seu texto publicado como prefácio a Sonhos D'ouro, em 1872. Ao apresentar esse romance, Alencar procura defendê-lo de uma crítica que parecia comum à época, a ausência de cor local que enfatizasse a nacionalidade da obra literária. Antecipando as críticas que imagina que sua obra sofreria, afirma: "versarão estas [críticas], se não me engano, principalmente sobre dois pontos, teu peso e tua cor. Achar-te-ão muito leve, e demais, arrebicada à estrangeira [...] (ALENCAR, 1959, p. 11). E continua: "quanto ao segundo defeito que te hão de notar, de ires um tanto desbotado do matiz brasileiro, sem aquele picante sabor da terra: provém isso de uma completa ilusão dos críticos a respeito da literatura nacional" (Ibid.). Alencar critica o que ele chama de "futilidades do patriotismo" daqueles que "professam a nacionalidade como uma religião", e propõe sua própria teoria de uma literatura nacional, que procura libertá-la da tal camisa de força do descritivismo. Para Alencar,

A literatura nacional que outra coisa é se não a alma da pátria, que transmigrou para este solo virgem com uma raça ilustre, aqui impregnou-se da seiva americana desta terra que lhe serviu de regaço; e a cada dia se enriquece ao contacto de outros povos e ao influxo da civilização (Ibid., p. 12). 
A proposta de Alencar para uma literatura nacional, ao mesmo tempo que rompe com o ranço antilusitano dos primeiros românticos, sendo os portugueses aqui apontados como uma "raça ilustre", também se descola da exigência de uma marca pitoresca e original proposta por Denis, avesso a toda modernização ou estrangeirização da sociedade brasileira. Para Alencar, o contato com os estrangeiros não descaracterizaria nossa cultura, mas a enriqueceria. Alencar apresenta ainda, neste prefácio, um breve panorama histórico-temático da literatura brasileira, que serve para classificar e explicar sua obra. Nesse esquema, Alencar divide a literatura brasileira em três fases: a primitiva, a histórica e a independência, que, por sua vez, divide-se entre a cidade e o campo. Como explica Alencar, a primeira fase, a primitiva, "que se pode chamar de aborígene, são as lendas e mitos da terra selvagem conquistada" (Ibid.). A essa fase corresponderia seu livro Iracema. A segunda fase, a histórica, "representa o consórcio do povo invasor com a terra americana, que dele recebia a cultura", é quando se formam novos costumes, pautados por um diverso clima (ALENCAR, 1959, p. 13). A essa fase correspondem O Guarani e As minas de prata. Na terceira fase, começada com a independência política, "a poesia brasileira, embora balbuciante ainda, ressoa não já somente nos rumores da brisa e nos ecos da floresta, senão também nas simples cantigas do povo e nos íntimos serões da família" (ALENCAR, 1959, p. 13). Esse momento produz duas diferentes realidades e temas literários: os lugares "onde não se propaga com rapidez a luz da civilização", e onde se encontram ainda "em sua pureza original [...] esse viver singelo de nossos pais, tradições e costumes e linguagem", recantos "que guardam intacto, ou quase, o passado", são representados por obras como O Tronco do Ipê, Til e O Gaúcho. Aqueles lugares como a Corte, onde há a contínua importação de ideias, onde se opera a "luta entre o espírito conterrâneo e a invasão estrangeira", são representados por romances como Lucíola, Diva e A Pata da gazela (Ibid., p. 14). Fazendo um paralelo, a fase primitiva proposta por Alencar corresponderia ao indianismo, a histórica é a própria, e os dois momentos da fase da independência, equivaleriam ao regionalismo (o campo), e ao romance de costumes (a cidade). Como notamos anteriormente, a proposta de Alencar se destaca da de Denis por sua aceitação de uma contínua influência estrangeira como constituidora de nossa identidade cultural, 
o que é rejeitado pelo olhar em busca de exotismo de Denis. Como o próprio Alencar esclarece ainda no prefácio a Sonhos D'ouro, ao tratar da nacionalidade do brasileiro:

\begin{abstract}
Notam-se aí, através do gênio brasileiro, umas vezes embebendo-se dele, outras invadindo-o, traços de várias nacionalidades adventícias: é a inglesa, a italiana, a espanhola, a americana, porém especialmente a portuguesa e a francesa, que todas flutuam, e a pouco e pouco vão diluindo-se para infundir náalma da pátria adotiva, e formar a nova e grande nacionalidade brasileira (ALENCAR, 1959, p. 14).
\end{abstract}

Alencar aceita a ideia da mestiçagem cultural defendida por Denis como definidora da cultura brasileira, mas expande as três raças apresentadas por Denis para as diversas contribuições de outras nacionalidades, que continuam atuando na constituição do país. Enquanto Denis propõe uma imagem fixa, mítica e original, um passado perdido (que deveria ser recuperado e congelado, como um animal extinto empalhado e exposto em um museu) para a nação, Alencar, sem desprezar a possibilidade de trabalhar com essa imagem mítica e exótica, abre o caminho para uma imagem do país em formação e multicultural.

Se uma boa parte da prosa que se desenvolveu ao longo do século XIX buscou desenvolver aqueles temas que Denis havia proposto para a construção da literatura nacional brasileira, a poesia, por sua vez, relacionou-se de forma mais crítica com a tradição descritiva. Na primeira geração romântica, a proposta de Denis adquiriu forma por meio da exploração do indianismo, da descrição da natureza brasileira, e da crônica histórica como matéria de seus poemas, construindo um discurso ufanista estreitamente alinhado ao estabelecimento do Império brasileiro representado pelos nomes de Gonçalves de Magalhães, Araújo Porto-Alegre e Gonçalves Dias. A geração seguinte, chamada por muitos de ultrarromântica, no entanto, seguiu por uma trilha diferente, ao adotar a poética do byronismo. Diretamente influenciados por narrativas exóticas, de um exotismo que nada tem de tropical, mas que é repleto de ruas estreitas de Veneza, de florestas sombrias do hemisfério norte e de castelos europeus, esses poetas, num movimento que lembra o dos árcades, abandonaram as descrições da natureza tropical e dos costumes brasileiros 
para se projetarem na paisagem europeia. Além do gosto pela ambientação europeia, outro motivo que fez a paisagem brasileira desaparecer em muitos poemas dessa geração se encontra na exacerbação do lirismo subjetivo, tornando a paisagem interior mais importante do que a exterior, aos olhos do poeta. Nenhum outro poeta representou tão plenamente essa geração como Álvares de Azevedo. Como afirma José Veríssimo, em sua História da literatura brasileira, avaliando a presença do descritivo em sua obra:

Álvares de Azevedo não é um poeta descritivo, um paisagista, conforme mais ou menos serão quase todos os nossos depois dele. Quando, porém, acerta de ter uma inspiração da natureza, à sua emoção mistura-se infalivelmente a mulher e o amor, reagindo sobre a materialidade da impressão e idealizando-a. Vejam Tarde de verão, Tarde de outono, em que ao descritivo inculcado pelo título se substituem puras sensações subjetivas (VERÍSSIMO, 1963, p. 249).

Álvares de Azevedo concentrou em sua obra e vida, em altos níveis, todas as características atribuídas ao movimento do qual fez parte. Sua obra se opõe, de forma direta e mesmo declarada, à poética nacionalista dos primeiros românticos. Abandonando a descrição da paisagem tropical, dos eventos históricos, dos temas indígenas, e mesmo os hinos ufanistas à pátria, Azevedo prefere descrever-se em meio às tavernas inglesas e praias do Mediterrâneo. A Itália é também um dos cenários favoritos para os poemas de Azevedo, dentre os quais o mais emblemático seria "Itália". Uma ode às belezas do país estrangeiro, aqui representado como o cenário romântico ideal, local para onde o poeta desejaria transportar-se e mesmo morrer. O poema é quase uma paródia ao tema poético do exílio, inaugurado por Gonçalves de Magalhães e celebrizado por Gonçalves Dias. Mas aqui, utilizando-se das mesmas imagens das praias, da vegetação típica, e da morte como retorno à origem, Azevedo inverte a rota e dirige seu canto não à pátria, mas a uma terra estrangeira, distante e desconhecida. Gonçalves de Magalhães, em seu "Adeus à Europa", presente nos Suspiros poéticos e saudades, de 1836, cantou:

Oh lira do meu exílio,

Da Europa as plagas deixemos;

Eu te darei novas cordas,

Novos hinos cantaremos. 
Adeus, oh terras da Europa!

Adeus, França, adeus, Paris!

Volto a ver terras da Pátria,

Vou morrer no meu país.

(MAGALHÃES, 1939, p. 367)

E dez anos depois, em 1846, a famosa "Canção do exílio", de Gonçalves Dias fez coro:

Nosso céu tem mais estrelas,

Nossas várzeas têm mais flores,

Nossos bosques têm mais vida,

Nossa vida mais amores.

[...] Minha terra tem palmeiras,

Onde canta o sabiá.

Não permita Deus que eu morra,

Sem que eu volte para lá; [...]

(DIAS, 1998, p. 105)

Álvares de Azevedo, no entanto, numa atitude mesmo provocativa, no poema "Itália", de 1851, abandona o canto das delícias do Brasil para sonhar com as plagas italianas:

Lá na terra da vida e dos amores

Eu podia viver inda um momento...

Adormecer ao sol da primavera

Sobre o colo das virgens de Sorrento!

(AZEVEDO, 2002, p. 79)

Se para Gonçalves Dias "nossos bosques têm mais vida/ nossa vida mais amores", Azevedo não se intimida em remendálo, afirmando que é a Itália "a terra da vida e dos amores". As palmeiras são substituídas pelas plantas europeias, e enquanto Gonçalves Dias relembra as palmeiras e sabiás brasileiros, é entre os loureiros e os laranjais italianos que Azevedo deseja morrer, desprezando o solo pátrio como túmulo:

Lá entre os laranjais, entre os loureiros,

Lá onde a noite seu aroma espalha,

Nas longas praias onde o mar suspira

Minh'alma exalarei no céu da Itália!

(Ibid., p. 79)

Mais do que uma rebeldia de gerações que se opõem, ou de uma suposta alienação frente à questão nacional pela adoção de um modelo poético estrangeiro da moda, podemos notar 
na geração de Azevedo um tom crítico frente à pronta adesão da primeira geração romântica ao discurso nacionalista do Império. Num primeiro momento, o abandono da realidade brasileira como tema poético em favor da adoção de uma estética, uma poética e realidade totalmente europeias, sugere um aparente retrocesso no processo de independência literária e construção de uma identidade nacional deflagrados pelo Romantismo brasileiro, que propunha exatamente o abandono dos temas europeus para tratar na literatura da história e da experiência brasileiras. Por outro lado, podemos identificar nesse distanciamento não apenas uma postura desafiadora frente ao nacionalismo literário ufanista dos primeiros românticos como também uma atitude intelectual mais crítica, embrião de um radicalismo político e social, que nesse momento se encontra diluído pelo lirismo subjetivista, mas que irá se desenvolver plenamente na geração seguinte com Castro Alves.

O exemplo de Álvares de Azevedo é um extremo. Nenhum de seus contemporâneos, inclusive byronistas de seu círculo estreito, como Bernardo Guimarães, foram tão adversos à adoção de temas nacionais em suas diversas formas (indianismo, patriotismo, história, regionalismo) quanto ele o fora. Sua atitude crítica frente ao nacionalismo descritivo é apresentada de forma declarada no trecho de Macário (1855) em que Penseroso comenta o livro de poemas do personagem título. Penseroso acha o livro de Macário muito triste e cético, e não entende porque tanta melancolia e desilusão em uma alma tão jovem (crítica que poderia ser diretamente feita à pessoa de Álvares de Azevedo), e por que não se dedicou a cantar sua pátria. Penseroso pergunta:

[...] e esse Americano não sente que ele é o filho de uma nação nova, não a sente o maldito cheia de sangue, de mocidade e verdor? Não se lembra que seus arvoredos gigantescos, seus oceanos escumosos, os seus rios, suas cataratas, que tudo lá é grande e sublime? Nas ventanias do sertão, nas trovoadas do sul, no sussurro das florestas à noite não escutou nunca os prelúdios daquela música gigante da terra que entoa amanhã a epopéia do homem e de Deus? Não sentiu ele àquela sua nação infante que se embala nos hinos da indústria européia como Júpiter nas cavernas do Ida ao alarido do Corihantes - tem futuro imenso? 
Esperanças! Não tê-las quando todos as têm! Quando todos os peitos se expandem como as velas de uma nau, ao vento do futuro! Por que antes não cantou a sua América como Chateaubriand e o poeta de Virgínia, a Itália como a Mignon de Goethe, o Oriente como Byron [...] (AZEVEDO, 1982, p. 63)

Quase como uma defesa de Álvares de Azevedo aos prováveis detratores de sua obra, um mea culpa, o poeta defende-se, criticando seus contemporâneos românticos, através da voz de Macário, que responde:

Falam nos gemidos da noite no sertão, nas tradições das raças perdidas da floresta, nas torrentes das serranias, como se lá tivessem dormido ao menos uma noite, como se acordassem procurando túmulos, e perguntando como Hamlet no cemitério a cada caveira do deserto o seu passado.

Mentidos! Tudo isso lhes veio à mente lendo as páginas de algum viajante que se esqueceu talvez de contar que nos mangues e nas águas do Amazonas e do Orenoco há mais mosquitos e sezões do que inspiração, que na floresta há insetos repulsivos, répteis imundos; que a pele furta-cor do tigre não tem o perfume das flores - que tudo isto é sublime nos livros, mas é soberanamente desagradável na realidade! (Ibid., p. 65)

Para Macário, os poetas que escrevem sobre as distantes regiões do Brasil, que eles próprios desconhecem, apenas repetindo as descrições feitas pelos viajantes estrangeiros, pouco ou nada sabendo da realidade que descrevem, não fazem algo muito diferente do que ele sonhando com Veneza e as praias italianas. Ambos trabalham com idealizações, e suas paisagens apenas servem para evocar diferentes perspectivas do exótico.

Como afirmamos anteriormente, não entendemos o discurso literário de Azevedo como uma alienação, ou retrocesso, do ponto de vista da construção de uma literatura nacional, mas como uma marca de um acentuado inconformismo, como demonstra a sua defesa apresentada no trecho de Macário citado, mostrando que o poeta estava atento à crítica de que sua obra fosse estrangeirada e alienada. O mesmo tipo de defesa (a respeito da ausência de cor local em sua obra), que Alencar faria mais tarde, 1872, no prefácio de Sonhos D'ouro, como vimos anteriormente. Daí seu distanciamento da estética nacionalista em sua produção literária, e a adoção de modelos 
estrangeiros sem a devida aclimatação segundo os preceitos românticos brasileiros da época.

A tendência da crítica brasileira em valorizar a representação do país como critério de qualidade de uma obra literária se difundiu e gerou polêmicas. Estabelecida no Resumé de Ferdinand Denis, que a utilizou como critério para selecionar as obras a constarem de sua história literária (ZILBERMAN, 2006), essa tendência crítica persistiu no decorrer do século XIX com os historiadores e críticos do Romantismo, e mesmo após esse movimento, podendo ser representada já no final do século XIX pela chamada Escola do Recife, que revestiu a velha ideia nacionalista e romântica de um verniz cientificista, como nos lembra Roberto Ventura, recordando a precedência de Sílvio Romero frente ao grupo:

A crítica e a história literária de Sílvio Romero fazem parte da Escola de Recife, participante da virada antirromântica a partir de 1870. A escola introduziu o naturalismo, o evolucionismo e o cientificismo, e tomou os conceitos de raça e natureza, com o fim de dar fundamentos 'objetivos' e 'imparciais' ao estudo da literatura. Os críticos naturalistas abordavam o texto como reflexo de condições sociais e naturais, e adotavam como critério de valor o grau de correspondência entre literatura e sociedade. As obras são tomadas como 'documentos' que revelariam a 'psicologia' de um século ou raça. Os 'monumentos', as obras como realizações artísticas ou estéticas, só teriam valor em função de sua 'representatividade'. O naturalismo deu continuidade à concepção documentalista da realidade brasileira, herdada da tradição romântica, em que o retrato da natureza tropical e dos costumes indígenas se impunha como programa literário nacionalizante. Críticos naturalistas, como Sílvio Romero, Araripe Jr., e Capistrano de Abreu, remetiam as 'origens' da literatura nacional à ação da miscigenação ou da natureza tropical sobre as formas europeias. (VENTURA, 2001, p. 10)

Uma das polêmicas geradas pelo critério nacionaldescritivo foi a travada entre Sílvio Romero e Machado de Assis, que teve sua obra desqualificada pelo crítico em razão da ausência de cor local e do caráter nacional em seus romances, sendo acusado de estrangeirismo. A essa questão, Machado respondeu com o ensaio "Instinto de nacionalidade", publicado em 1873. Nesse texto, em que apresenta sua própria teoria de uma literatura nacional, Machado de Assis se revolta contra o 
critério nacionalista-descritivo, e estabelece um novo parâmetro na crítica literária nacional. Ao defender os árcades e relativizar o papel do indianismo e da natureza na literatura brasileira, Machado critica os que só reconhecem espírito nacional nas obras que tratam de assunto local. E defende um nacionalismo que não se restrinja ao superficial, e nem seja limitado:

Não há dúvida que uma literatura, sobretudo uma literatura nascente, deve principalmente alimentar-se dos assuntos que lhe oferece a sua região, mas não estabeleçamos doutrinas tão absolutas que a empobreçam. $\mathrm{O}$ que se deve exigir do escritor antes de tudo, é certo sentimento íntimo, que o torne homem do seu tempo e do seu país, ainda quando trate de assuntos remotos no tempo e no espaço. (ASSIS, 1992, p. 804)

Machado não descarta o indianismo e a descrição da natureza como temas, tendo ele próprio se aproveitado de ambos, mas não aceita circunscrever nossa literatura a esses aspectos, assim como relativiza a propriedade de sua onipresença, sempre de forma conciliadora, como afirma, ao criticar os escritores brasileiros que seguiam tenazmente essa tendência: "há boas páginas, como digo, e creio até que um grande amor a este recurso da descrição, excelente, sem dúvida, mas (como dizem os mestres) de mediano efeito, se não avultam no escritor outras qualidades essenciais" (Ibid.). Concebida como uma literatura de exportação (como mais tarde proporia Oswald de Andrade, recuperando o uso do exótico como projeto literário nacional), nossa literatura romântica, presa ao descritivismo e exotismo propostos por Denis, responderia, portanto, muito mais a uma demanda externa do que a questões internas, como parece reconhecer Machado em seu texto. É dessa forma que nota a ausência no Brasil, do romance de análise, e de temas morais, políticos e sociais:

Isento por esse lado o romance brasileiro, não menos o está de tendências políticas, e geralmente de todas as questões sociais, - o que não digo por fazer elogio, nem ainda censura, mas unicamente para atestar o fato. Esta casta de obras, conserva-se aqui no puro domínio de imaginação, desinteressada dos problemas do dia e do século, alheia às crises sociais e filosóficas. Seus principais elementos são, como disse, a pintura dos costumes, e luta das paixões, os quadros da natureza, alguma vez o estudo dos sentimentos e dos caracteres [...] (ASSIS, 1992, p. 805) 
Ao deter-se na poesia, Machado critica a grandiloquência na descrição da natureza:

Bem sei que as cenas majestosas da natureza americana exigem do poeta imagens e expressões adequadas. O condor que rompe dos Andes, o pampeiro que varre os campos do Sul, os grandes rios, a mata virgem com todas as suas magnificências de vegetação, - não há dúvida que são painéis que desafiam o estro, mas, por isso mesmo que são grandes, devem ser trazidos com oportunidade e expressos com simplicidade. (Ibid., p. 807)

Assim como critica a descrição pela descrição, que se torna um inventário de registros:

Há também uma parte da poesia que, justamente preocupada com a cor local, cai muitas vezes numa funesta ilusão. Um poeta não é nacional só porque insere nos seus versos muitos nomes de flores ou aves do país, o que pode dar uma nacionalidade de vocabulário e nada mais. Aprecia-se a cor local, mas é preciso que a imaginação lhe dê os seus toques, e que estes sejam naturais, não de acarreto. (Ibid.)

Machado acaba por desvelar um ponto fraco de parte de nossa literatura, que no afã de nacionalizar-se, mantémse atada a um nacionalismo superficial, que agrada mais ao estrangeiro do que reflete a realidade do país. Ao procurar construir seu discurso nacionalista deixando de atender aos anseios de uma nação que se forja imersa em problemas econômicos, políticos e sociais, e buscando representações míticas indígenas ou descrições pitorescas da natureza e dos costumes, essa forma de literatura criticada por Machado acaba ocupando apenas o espaço reservado ao exótico pelo olhar europeu. Não responde, portanto, às questões de nossa realidade, mas a estiliza para o estrangeiro, segundo as convenções por ele estipuladas. Machado, não apenas em seu pensamento, como em sua obra, foi um dos poucos escritores brasileiros que conseguiram propor uma literatura altamente identificada com a sociedade brasileira, sem precisar atender ao descritivismo e ao nacionalismo ufanista.

Mais tarde, com a publicação do livro sobre o escritor, Machado de Assis, em 1897, Romero iria apresentar uma versão mais apaziguada de sua relação com o autor de Brás Cubas, mas sem deixar de mostrar sua declarada antipatia. Na obra em que apresenta seu estudo de Machado, Romero nos dá 
uma diferente versão da levantada acima por Ventura para sua crítica literária, e quase repetindo as ideias presentes no "Instinto de nacionalidade", defende-se:

Outro preconceito que é mister arredar é o de não poder o autor de Iaiá Garcia ser apreciado pelo critério nacionalista. Machado de Assis pode e deve ser julgado pelo critério nacionalista [...]. A inspiração nacionalista não é, ao que se repete vulgarmente, a que é mais pegada à vida nacional. Se assim fora, não teríamos dado importância a Álvares de Azevedo, Laurindo Rabelo, Aureliano Lessa, Varela, Castro Alves, Tobias Barreto, que, entre os românticos, estão na primeira fila dos poetas, já não falando no velho Cláudio da Costa, que ocupa o primeiro posto entre os clássicos. [...] $\mathrm{O}$ espírito nacional não está estritamente na escolha do tema, na eleição do assunto, como se costuma supor. Não é mais possível hoje elaborar em tal mal entendu. O caráter nacional, esse quid quase indefinível, acha-se, ao inverso, na índole, na intuição, na visualidade interna, na psicologia do escritor. (ROMERO, 2001, p. 280)

Apesar de aparentemente voltar atrás em suas ideias sobre o caráter da literatura nacional, Romero não deixa de criticar, ainda que de forma enviesada, a ausência descritiva em Machado, ao prosseguir seu texto. Segundo ele, apesar de um bom criador de tipos brasileiros, "faltava-lhe a imaginação vivaz, alada, rápida, apreensora, capaz de reproduzir as cenas da natureza ou da sociedade, e daí a sua incapacidade descritiva e seu desprazer pela paisagem" (ROMERO, 2001, p. 281). E vai mais além, ainda tratando das carências de Machado de Assis:

Não conhece essa intimidade com os grandes fenômenos externos, a embriaguez pelas fortes cenas das montanhas, dos mares, dos campos, das matas; nem a efusão inebriante do espetáculo dos céus imensos ou profundos, ou sombrios, ou brilhantes, ou borrascosos, ou azuis, ou estrelados; nem as cenas inefáveis das manhãs e das tardes tropicais, as mil cambiantes da paisagem, a eloquência infinita e muda, o quebranto intraduzível das noites calmas e estivais. [...] nada de fortes descrições, de amplos quadros, de vigorosas cenas, de reproduções realistas do mundo. [...] O nosso romancista não tem grande fantasia representativa. Em seus livros de prosa, como nos de versos, conforme deixamos notado, falta completamente a paisagem, falham as descrições, as cenas da natureza, tão abundantes em Alencar, e as da história e da vida humana, tão notáveis em Herculano e em Eça de Queirós. (ROMERO, 2001, p. 282-84) 
José Veríssimo, por sua vez, reconheceu logo a peculiaridade da obra de Machado, como afirma na sua História da literatura brasileira, lançada em 1916, e rejeitando o critério nacionalista-descritivo:

Entre os nossos escritores, todos mais ou menos atentos ao pitoresco, aos aspectos exteriores das cousas, todos principalmente descritivos ou emotivos, e muitos resumindo na descrição toda a sua arte, só por isso secundária, apenas ele [Machado de Assis] vai além e mais fundo, procurando, sob as aparências de fácil contemplação e igualmente fácil relato, descobrir a mesma essência das cousas. É outra das suas distinções e talvez a mais relevante (VERÍSSIMO, 1954, p. 350)

A tendência nacionalista-descritiva, porém, dominou boa parte da produção do século XIX. Como bem resume Bosi, "de Magalhães e Varnhagen, a Castro Alves e Sousândrade, dos indianistas e sertanistas aos condoreiros, transmite-se o mito da terra mãe, orgulhosa do passado e dos filhos, esperançosa do futuro" (BOSI, 2006, p. 154). Ou, como nota Candido, também resumindo o período "em todos os românticos, de Macedo e Alencar a Bernardo de Guimarães e Franklin Távora, ressalta a atenção ao meio, ao espaço geográfico e social onde a narrativa se desenvolve" (CANDIDO, 2007, p. 433). E estende seu comentário também à poesia: "é uma constante não desmentida de toda a nossa evolução literária, que a verdadeira poesia só se realiza no Brasil, quando sentimos na sua mensagem certa presença dos homens, das coisas, dos lugares do país" (CANDIDO, 2007, p. 115). Outros, porém, criticam essa vertente nacionalista-descritiva, como Fausto Cunha, para o qual "o caráter nacionalista da inspiração de um poeta é um aspecto positivo, mas não devemos ficar surpresos de descobrirmos que se trata de um nacionalismo de torna-viagem, nem tão ingênuos a ponto de aceitarmos como autenticamente nosso, o que nos impigem como tal" (CUNHA, 1971, p. 136). Cunha tocou numa das questões centrais de nossa constituição, o que chamo de olhar refratado do brasileiro, um olhar que não se observa diretamente, mas que é filtrado pelo olhar estrangeiro, e que acaba por selecionar como autenticamente nacionais, aqueles elementos destacados pelo olhar do estrangeiro. Esse processo que, no início do nosso Romantismo, foi tão bem corporificado na obra de Ferdinand Denis, não apenas se 
estendeu ao longo do século XIX como continuou a servir de pano de fundo para discussões que avançaram no século $X X$ com o movimento modernista, também marcado por um viés nacionalista-descritivo.

\section{REFERÊNCIAS}

ALENCAR, J. Sonhos d'ouro. São Paulo: Saraiva, 1959.

ASSIS, M. Instinto de nacionalidade In: . Obra completa. Vol. III. Org. Afrânio Coutinho. Rio de Janeiro: Nova Aguilar, 1992.

AZEVEDO, A. Macário. Campinas: Unicamp, 1982.

. Poesias completas. Campinas/São Paulo: Unicamp/ Imprensa Oficial, 2002.

BOSI, A. História concisa da literatura brasileira. São Paulo: Cultrix, 1975.

CANDIDO, A. Formação da literatura brasileira. Belo Horizonte: Itatiaia, 2007.

. Literatura e sociedade. São Paulo: Editora Nacional, 1976.

CUNHA, F. O Romantismo no Brasil. De Castro Alves a Sousândrade. Rio de Janeiro: Paz e Terra, 1971.

DENIS, F. Scènes de la nature sous les tropiques, et leur influence sur la poésie, suivi de Camões et Jozé Índio. Paris: L. Janet, 1824.

. Résumé de l'Histoire du Portugal, suivi du Resume de l'Histoire Literaire du Brésil. Paris: Lecointe et Durey, 1826.

. Resumo da história literária do Brasil. Tradução, prefácio e notas de Guilhermino César. Porto Alegre: Lima, 1978.

DIAS, G. Prosa e poesia completa. Rio de Janeiro: Nova Aguilar, 1998.

HOLANDA, S. B. (Org.). História geral da civilização brasileira. São Paulo: Difel, 1986.

MAGALHÃES, D. J. G.. Obras completas. Rio de Janeiro: Serviço Gráfico do Ministério da Educação, 1939.

Discurso sobre a história da literatura do Brasil. In: COUTINHO, A. Caminhos do pensamento crítico. Vol. 1. Rio de Janeiro: Editora Americana, 1974. p. 11-29.

MAGALHÃES JR., R. Poesia e vida de Álvares de Azevedo. São Paulo: Editora das Américas, 1962. 
RICOTA, L. A constelação espacial das cenas de origem em Scènes de la Nature, de Ferdinand Denis. Revista USP, São Paulo, n.91, p. 112-124, setembro/novembro 2011.

ROMERO, S. Compêndio de história da literatura brasileira. Rio de Janeiro: Imago, 2001.

ROUANET, M. H. Eternamente em berço esplêndido. A fundação de uma literatura nacional. São Paulo: Siciliano, 1991.

SODRÉ, N. W. História da literatura brasileira. Rio de Janeiro: Graphia, 2002.

VENTURA, R. História e crítica em Sílvio Romero. In: ROMERO, S. Compêndio de história da literatura brasileira. Rio de Janeiro: Imago, 2001. p. 9-21.

VERÍSSIMO, J. História da literatura brasileira. Rio de Janeiro: José Olympio, (1954) 1963.

ZILBERMAM, R. Ferdinand Denis e os paradigmas da história da literatura. In: Revista do Programa de Pós-Graduação em Letras da Universidade de Passo Fundo -, Passo Fundo, v. 2, n. 1, p. 137147, jan./jun. 2006.

O Resumo de História Literária, de Ferdinand Denis: história da literatura enquanto campo de investigação. Veredas, Santiago de Compostela, N. 19, p. 121-144, 2013. 


\section{Abstract \\ Brazilian romantics and the national- descriptive tendency in the literature of the 19th century}

Brazilian Romantic literature was developed in a period of intense national affirmation and under the influx of the ideas of French writer Ferdinand Denis. Author of the first Brazilian literary history, published in 1826, Denis advocated to the newly-founded nation in this book a new literary program grounded on the representation of tropical landscape as a mark of originality and nationality. Considering the pervasive presence of Denis' ideas in Brazilian Romantic literature, this paper presents a study of the indirect and direct references to Denis' literary proposal in some works and texts written by representative names of Brazilian literature throughout the 19th century. Beyond the resonances of Denis' ideas, this paper points out the way some writers adapted them to Brazilian social-historical context. It also demonstrates the counter reaction of those authors who denounced the limits of such proposal of a descriptive-nationalist literature, which came to guide a large branch of Brazilian Romanticism.

Keywords: Ferdinand Denis; Brazilian Literary History; Romanticism. 